\title{
Negotiating the Early Childhood Education Revolution: An Exercise in Multi-level Governance
}

\author{
Trish Mercer and Wendy Jarvie
}

\section{Introduction}

When Kevin Rudd's Labor Government came to power in November 2007, state and territory premiers and chief ministers were amongst those most keenly anticipating a 'change of guard' in Canberra. Before the year had ended, the new prime minister had chaired his first Council of Australian Governments (COAG) meeting, an historic all-Labor meeting that agreed to institute 'a new model of cooperation underpinned by more effective working arrangements' and the corresponding development of a new Commonwealth-state financial relations framework. ${ }^{1}$ Over the next year, the frenetic activity that took place through COAG's workinggroup processes produced this new architecture based on a level of cooperation and collaboration that sharply contrasted with the previous decade of conflict and disharmony (Anderson and Parkin 2010: 99). 
The implementation of the Rudd Government's major election commitment to achieve universal access to 15 hours of preschool weekly for all Australian four-year-olds by 2013 was a new reform agenda caught up in these processes. For early childhood education (ECE), this episode in contemporary federal dynamics would be characterised by a number of elements that were more typical of what is termed multi-level governance (MLG) than classic federalist governance approaches to cooperative policymaking. This case study, prepared from our perspective as former Commonwealth education bureaucrats closely involved in implementing this reform, will examine why ECE became a national priority at this time and to what extent the processes of building ECE into COAG's new framework incorporated an MLG orientation. ${ }^{2}$

\section{Early childhood education: The policy challenge}

In the opening years of the 21 st century, national and international commentators agreed on the complexity of educational offerings in the year before formal schooling for four-year-olds across Australia: preschool $^{3}$ was a labyrinth of conflicting terminology, diverse service types, uneven quality, limited funding provision and confusing regulatory environments in both education and community services. The current landscape was the legacy of a divided system, with the growth of state government oversight and funding of preschools following the kindergarten movement in the late 19th century, whereas the Commonwealth had focused its policy and funding support instead on supporting formal child care, building on the private and philanthropic day nurseries from the early 20th century but increasingly provided in private, long day care centres. Significant variations in preschool offerings had developed due to this bifurcation between ECE on the one hand and care on the other.

2 This chapter is based on an Australia and New Zealand School of Government (ANZSOG) case study (Mercer 2016).

3 Preschool has been adopted by COAG as the generic term for the education received by children (usually four-year olds) in the year before formal schooling. The diversity of terms employed across Australia is highlighted in an Australian Council for Educational Research report (Dowling and O’Malley 2009: 2-3). 
In broad terms, the country was split between two models of preschool provision: across the most populous eastern Australian states of New South Wales, Queensland and Victoria, the state governments subsidised preschool services, which were delivered by non-government organisations; by contrast, in the remaining states and territories, most preschool services were delivered by, as well as funded through, the government education system. ${ }^{4}$ This division, however, was complicated by specific jurisdictional variations (for example, New South Wales also funded and delivered a number of government preschools) and by the increasing eagerness of non-government schools to offer school-based preschool. Outside this 'badged' preschool system, moreover, there were also preschool-program offerings of variable quality in many long day care centres. For parents, it was confusing and frustrating to negotiate the early childhood education and care (ECEC) maze - to know, for example, what their long day centre offered beyond safe babysitting; how to balance work and family, especially if they faced the dreaded 'double drop-off' of one child in care and another in sessional preschool; or how to afford the high preschool fees existing in some states, particularly New South Wales.

Given the diversity of preschool delivery, the compilation of any national picture was a fraught exercise. An annual picture, but only of governmentprovided or subsidised preschool, was provided in the Productivity Commission's Report on Government Services (although this was qualified by data quality issues, such as double counting): for 2007-08, it reported that 69.9 per cent of four-year-old children were enrolled in such preschool services, receiving between 11 and 13 hours of preschool per week. ${ }^{5}$ A particular problem, given the critical issue of Aboriginal and Torres Strait Islander disadvantage, was that the only available national figures for the number of Indigenous four-year-olds receiving preschool were collected through the then Commonwealth Department of Science, Education and Training (DEST) for the purpose of Indigenous preschool subsidies. In the years before the Rudd Government's election, such data limitations had a serious impact on policy development, creating a degree of uncertainty in the minds of policymakers as to the extent of preschool coverage, including for key sub-populations.

4 These models and the additional variability at state/territory level are outlined in Dowling and O’Malley (2009: 4-5). The Commonwealth Department of Education, Science and Training also had a relatively small allocation (some $\$ 13$ million) to support the provision of Indigenous preschools across the country.

5 Steering Committee for the Review of Government Services Provision (2009: 3.21-3.23). 
Internationally, Australia consistently achieved a bottom ranking (at 30th) on early childhood provision in the annual education report by the Organisation for Economic Co-operation and Development (OECD), with a percentage of GDP ( 0.1 per cent) for 'pre-primary education' sitting well below the OECD average $(0.45$ per cent $) .{ }^{6}$ Data limitations notwithstanding, this was a telling figure in the policy debate, due to the sheer scale of the difference.

Reflecting the Commonwealth's focus on funding child care, early childhood responsibility at the national level (and also in some states) was in 2006 nested in the Families, Community Services and Indigenous Affairs (FaCSIA) portfolio. With no national policy on preschool or an early years curriculum framework, ECE did not feature in mainstream (i.e. schooling) educational debates, such as those on national curriculum and assessment and teacher training standards. Yet, neuroscience in the 1990 s discovered the importance of brain development in the early years for later skills formation. Such 'brain science' was transforming the understanding of researchers and policymakers of the importance of ECEC, reflected in initiatives in South Australia and Victoria to review their policies and profile early childhood development. This traditionally 'soft' area of public policy had also acquired a hard edge through the analyses of leading economists (such as Nobel Prize-winning James Heckman) of the impressive investment return from early childhood for human capital development, although the longitudinal studies cited as evidence were targeted to disadvantaged children (Elliott 2006: Sec. 3), rather than universally available.

As the Coalition Government under John Howard approached the end of its final term in 2007, there was increasing lobbying to address Australia's poor record in ECE and its low investment compared to that made in schools. Pressure was also mounting from some jurisdictions to reconsider the separation of care and education and the confusing regulatory roles played by the Commonwealth and states, fuelled in part by the increasing domination of private for-profit providers in long day care provision. On 10 February 2006, COAG made the landmark decision to include early childhood in its agenda for human capital reform, which signalled that this was finally a priority for public policy attention. By early

6 This OECD expenditure was for 2005 on institutions for pre-primary education and did not include Commonwealth expenditure on preschool delivered in child care centres (due to the absence of formally recorded data) and therefore underestimated Australia's spend (OECD 2008: Table B2.2). 
2007, however, with Commonwealth-state tensions intensifying in the pre-election period, the decision taken by COAG at its 13 April meeting reflected a relative stalemate on early childhood, with the Commonwealth having restricted reform proposals to the development of a national approach on quality assurance and regulations. ${ }^{7}$

\section{Reforming early childhood education: Labor's election promises}

At the start of the election year in January 2007, Kevin Rudd, as the new opposition leader, seized the initiative to profile ECE in the first major policy statement for his promised 'Education Revolution', citing the research into brain science and cost benefits of ECE investment as productivity drivers (McKew 2013: 129-30). 'New Directions for ECE' committed Labor to spend $\$ 450$ million a year by 2013 on achieving universal access for all Australian four-year-olds to 15 hours preschool weekly, delivered by four-year-degree qualified teachers, in public and private settings. Other early childhood election commitments included three significant workforce initiatives to boost the supply of early childhood teachers and child care workers, a national Early Years Learning (curriculum) Framework, an additional 260 'early learning centres' with integrated education and care, new quality standards for child care, and measuring the school readiness of every five-year-old child through the Australian Early Development Index (AEDI). ${ }^{8}$ Labor also promised to implement the OECD's recommendation for integrated, national leadership by transferring responsibility for ECEC to the education portfolio.

Following the election of the Rudd Government in November 2007, the administrative changes put in place in December 2007 duly established an Office of Early Childhood Education and Child Care (OECECC) in the new mega-department of Education, Employment and Workplace Relations (DEEWR), with Julia Gillard (then deputy prime minister) as the portfolio minister and Maxine McKew as parliamentary secretary for ECEC. With such an explicit reform agenda on ECE, there was

7 COAG Communiqué, 10 February 2006: 2 and Attachment A p. 2; COAG Communiqué, 13 April 2007: 4.

8 These were not the only election commitments in early childhood. For full details, see Rudd and Macklin (2007). 
a clear government expectation that the policy development phase had been undertaken and that the challenge was, therefore, to implement this element of the Education Revolution rather than to explore the implications of adopting this reform approach in such a complex and neglected policy area.

From its first days, the OECECC was immersed in planning for the implementation of universal access to preschool and other ECEC-related election commitments. A five-year expenditure plan of $\$ 533.5$ million for universal access leading up to full implementation in 2013 was developed, including an early offer of $\$ 10$ million for state and territory governments to invest immediately to support access to preschool for disadvantaged and Indigenous children. This initial funding was an effective way to begin a major reform process, in terms of exciting interest in ECE, building working relationships and acquiring knowledge of state priorities.

While this initial sweetener opened dialogue with state officials, Labor's election policy flagged two options for delivering the universal access funding: through the traditional route of state grants (known as specific purpose payments or SPPs) or direct Commonwealth grants to providers. Notwithstanding that there was no existing SPP and that ECE was delivered in both government and non-government settings, the universal access and other ECEC election commitments were quickly swept up into the bigger picture of Rudd's federalist reform agenda.

\section{Australian federalism and MLG}

In terms of the division of government between national and state/ territory (hereafter referred to as 'state') levels, the Commonwealth and states share intermeshed responsibilities in many social policy areas. Since the 1970s, the Commonwealth increasingly exercised its constitutional ability under section 96 to extend its influence by employing 'tied' or conditional grants (the SPPs). By 2000-01, such SPPs covered some 42 per cent of the total grants to states (Vromen et al. 2009: 306; Fenna 2009: 156).

The Howard years of government (1996-2007) were characterised by a strongly interventionist approach from the central government, which was manifest in the extension of conditionality under these SPPs, including to policy issues beyond the core funding rationale. Education was a sphere 
singled out for such regulatory federalism, with the Commonwealth tying compliance with contentious national policy initiatives to ongoing core funding - a stellar example being the requirement in school grants legislation that the state governments adopt a Commonwealth-approved and standardised form of student performance reporting in their schools (Vromen et al. 2009: 309; Miragliotta et al. 2010: 253).

Such an increasingly assertive Commonwealth approach to intergovernmental relations heightened the long-standing tensions between these two levels of government over the division of policy responsibility and the processes for establishing and maintaining an effective working relationship in common policy areas. As (Fenna 2004: 171) has observed:

'cooperative federalism' might have been a prerequisite in this working relationship but it was hardly an accurate description given the conflict and coercion which more often characterized the interactions in these years.

COAG, which had begun in a more cooperative period in 1992, was seen as a mechanism for the Commonwealth to push its policy positions rather than engage with the states in discussion and negotiation (Fenna 2004: 182; Vromen et al. 2009: 309).

The earlier Labor governments of Gough Whitlam, Bob Hawke and Paul Keating had also not been averse to employing tied grants as a vehicle to extend Commonwealth influence in key policy areas. While traditionally Labor governments had opposed federalism as an obstacle to national policymaking, since the 1970s, Labor has 'reconciled itself' to this fundamental characteristic of the political landscape (Galligan and Mardiste quoted in Fenna 2004: 184). Any view of federalism as a somewhat outdated political system had, moreover, been challenged by the emergence of a confederal united Europe and the rising number of federal countries. The new Rudd Government was known to have looked for inspiration to its UK counterpart, and particularly the social reformist policies of the British Government under Tony Blair, which was regarded as pro-European Union (EU) compared to its Conservative predecessors (Miragliotta et al. 2010: 226-27; Bache 2004: 175-77).

It was the creation of the integrated EU that stimulated the development in Europe of MLG as a concept and brought about its pervasiveness not only in academic discourse, but also in bureaucratic circles. While this is 
not yet the case in Australia, the complexity and level of difficulty of the policy decisions that are increasingly confronting governments demand more flexible and innovative approaches than are usually associated with governance arrangements under cooperative federalism. One of the values of MLG is that it draws our gaze to the adaptations required of governance in responding to this pattern of complex policy challenges, such as the challenge experienced by Commonwealth and state bureaucrats during 2008 of how to embed the Rudd Government's ECE election commitment within the design for the new federal financial relations architecture.

So how does MLG help us to understand Australian federalist processes of policy development in the contemporary environment? A core contribution is that it assists our understanding of how decision-making involving tiers of government occurs: instead of concentrating our attention solely on the vertical interactions between the two levels of government, MLG places a wider focus on governance and the dynamic, flexible and, importantly, more informal processes operating within a particular policymaking episode. This incorporates horizontal as well as vertical relationships, which may be less hierarchical and include the influence of non-government actors. The core MLG characteristic of 'continuous negotiation amongst nested governments at several territorial tiers' was first defined by Marks (1993: 392), one of the leading contributors to MLG literature (Bache and Flinders 2004: 3). MLG is also associated with a climate of cooperation in which mutual agreement and shared authority and responsibility are dominant, in contrast to the discord and competition that can be characteristic of federalism (Stein and Turkewitsch 2008: 14).

A further refinement in the development of MLG has been its subdivision into two types, of which Type I is relevant for this case study. Type I, which assumes many characteristics closely associated with federalism, is focused on power-sharing among governments operating at only a few levels, such as the Australian national government and the tier of states and territories, with their overlapping powers but with distinct boundaries. Such Type I MLG serves an institutional purpose of highlighting how power and sovereignty is divided between national and state levels in order to enable cooperative approaches to policymaking and to avoid overcentralisation of authority. Type II MLG, by contrast, is represented by policy structures that are more fragmented and numerous, and operates with more flexibility and variability (Stein and Turkewitsch 2008: 3, 9, 12; Bache and Flinders 2004: 5). 
MLG has been characterised by Kay as a 'label' for a phase of Australian federalism in a globalised economy era (Kay). In the face of demanding policy challenges, Australian federalism is seen to have become more fluid and innovative, thereby breaking free from the shackles of its federal design. This is illustrated by the move away from joint decisionmaking at the intergovernmental level towards majority voting, to avoid the 'joint decision trap' whereby one level of government can retain the status quo by vetoing any change (Kay; Stein and Turkewitsch 2008: 3). Painter has examined how majority voting became part of the Australian cross-governmental ministerial council deliberations from the late 1980s, although consensus typically prevails (Painter 1996). While it has no legislative underpinning, COAG has become a central institution for intergovernmental relations and the operation of what is described as 'executive federalism' (Blayden 2013: 58-59). COAG itself is supported by official committees and working groups to progress policy development between meetings, and this aspect of its operations was taken to a heightened level of activity under the Rudd Government.

\section{The ECE dimension of Rudd's COAG reform agenda}

During the 2007 election campaign, Rudd signalled his commitment to federalism as the means of progressing policy reform (Anderson and Parkin 2010: 97-98). His government's early determination to adopt a collaborative partnership approach to Commonwealth-state relations and to remove the major source of disharmony by redesigning the federal-financial framework and rationalising the SPPs was, therefore, perceived by the media and academic commentators as a return to cooperative federalism (Miragliotta et al. 2010: 69; Vromen et al. 2009: 31 ). Yet, in practice, the process that followed the December 2007 COAG meeting and dominated Commonwealth-state governmental interactions through 2008 can arguably be said to have displayed many characteristics associated with MLG in its Type I approach, at least for the ECE element. As one important indicator, in an acknowledged break with previous practice, Commonwealth ministers were to oversee working groups of senior officials covering the seven areas of COAG's 2008 work agenda, including SPP rationalisation, with nominated senior state officials (rather than the corresponding state minister) acting as deputies. Gillard, whom the media dubbed 'Minister for Productivity', chaired the so-called 
Productivity Agenda Working Group (PAWG), overseeing reform across early childhood, schools and skills, with Helen Silver (secretary of Victoria's Department of Premier and Cabinet) as her deputy. COAG'S objectives for this working group clearly signalled the new paradigm in that this was expected to involve:

additional effort, greater collaboration and sharper focus on improving outcomes - starting with the earliest years, and moving through school and into the training system (COAG Communiqué, 20 December, 2007: 6).

Not only was early childhood thus firmly positioned in the productivity agenda, but also the polarisation that had characterised education discussions over the last decade would be a thing of the past.

Just over a year down the track, Gary Banks, the productivity commissioner, would reflect on the 'novel design' of this new working group structure and 'the punishing dictates' for ministers and officials in responding to a tight timetable of four COAG meetings across 2008 (Banks 2009). ${ }^{9}$ Anderson and Parkin later described it as a 'quite remarkable innovation' (2010: 100). For officials in central agencies and line departments in Canberra and around the country, it was a gruelling schedule of meetings, pre and post meetings, teleconferences and briefings to support COAG and also the treasurers' ministerial council. To take forward the education and training work program, the PAWG quickly established three subgroups on schools, skills and workforce development and early childhood development (ECD), composed of senior officials from central agencies and line departments.

At the next COAG meeting, on 26 March 2008, COAG affirmed that the review of SPPs was a priority area, to establish 'genuinely collaborative working arrangements, including clearly defined roles and responsibilities and fair and sustainable financial arrangements to facilitate a long-term policy focus and reduce blame shifting' (COAG Communiqué, 26 March 2008). The SPPs would be contained in an intergovernmental agreement, to underpin the reforms. COAG also endorsed the specific aspirations, outcomes, COAG targets, indicative program measures and policy directions identified by the PAWG as the basis for its creation of new generation education SPPs that would, moreover, include implementation

9 Banks also referred to the complexity of the human capital agenda in terms of reform delivery and pointedly noted that Heckman's analysis of the benefits of preschool investment was based on programs for disadvantaged children (rather than universal provision). 
of federal election commitments. ${ }^{10}$ It would, however, take many months of robust discussions and intense negotiations through PAWG and its three subgroups to produce the draft input for the new Intergovernmental Agreement on Federal Financial Relations, which COAG would consider in November.

As the proverbial infant in the COAG Education family, early childhood did not fit easily into these processes. As mentioned previously, ECE had no existing SPP, so discussion seesawed back and forth as to whether it should be included with the schools SPP, given the importance of an effective transition to school, or be an agreement in its own right, given interest in the broader ECD agenda encompassing education, care and health. Under the new Commonwealth-state financial arrangements, there was also the capacity for new national partnership payments to support project delivery or drive reforms of national importance although this would be a part of the new COAG architecture that was more fluid during the year. Of the three subgroups to PAWG, only that reviewing ECD was chaired by the Commonwealth (DEEWR deputy secretary Wendy Jarvie), which reflected the new and evolving nature of this reform agenda.

There was, however, some frustration around the role for existing ministerial councils and their senior officials' groups, which were sidelined under these new arrangements, adding a further challenging element for Minister Gillard in bridging the two worlds between PAWG and the existing ministerial councils and groups of officials. ${ }^{11}$ Again, ECE was in an unusual position, having previously come under the purview of the community services ministers: a new Early Childhood Ministers Committee was now established as a satellite of the Ministerial Council for Education and Training Ministers, so that education and community services ministers with responsibility for early childhood matters could come together.

10 COAG Communiqué, 26 March 2008, Supplementary Information to that contained in the Communiqué: 1-2. The Human Capital Framework of the PAWG was later published in the Commonwealth's May Budget papers, as part of a broader communication strategy around the COAG processes (Gillard 2008: 22, 24-25).

11 This also created uncertainty for the role of Maxine McKew, as parliamentary secretary for early childhood, who later recalled that her relationship with Gillard, while 'workable', 'could have been a lot better' (McKew 2013: 122). 
As so often happens in reform processes, the early childhood reform agenda quickly expanded into a broader, indeed whole-of-government, agenda before the reality of what was possible in fiscal terms and in an overloaded policy environment impelled a pulling back and creation of parallel processes (see Figure 7.1).

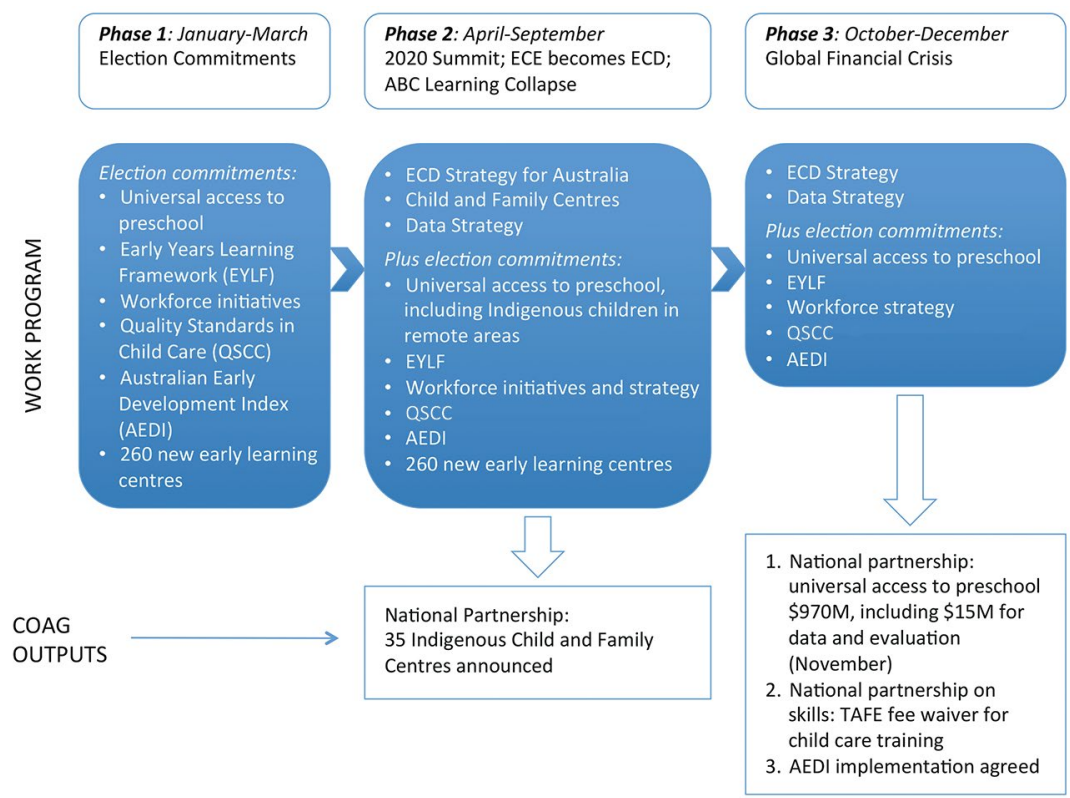

Figure 7.1: The Early Childhood Development (ECD) Subgroup work program, 2008

Source: Trish Mercer and Wendy Jarvie

Prime Minister Rudd, in his powerful 'Sorry' speech delivered to Parliament and the nation in February 2008, committed to providing access within five years to a quality preschool program for all Indigenous four-year-olds in remote communities - this was quickly added as an additional ECE target at the March COAG meeting (COAG Communiqué, 26 March 2008: 7). This meeting also agreed that the ECD program would include the development of quality standards and a rating system for child care and preschool (another election commitment). Given the expansive policy environment, bureaucrats on the ECD subgroup began work on a broad canvas of early child care reform across the interrelated spheres of education, families, health and Indigenous affairs. 
The prime minister signalled his interest at his 2020 'Ideas' summit in integrating early childhood interventions through the medium of child and family centres. In July, COAG agreed to the development of a broader national strategy for ECD that would include child and family centres (COAG Communiqué, 3 July 2008: 6). With the map of the new federalism being drawn up concurrently, the ECD subgroup found its task both complex and ambiguous, with changing and sometimes conflicting advice over issues such as whether policy and funding should be dealt with separately and whether it should develop a national agreement with national partnerships hanging off it or begin with just one focused national partnership.

As the year progressed, however, the reform climate became less expansive. In July 2008, under pressure from the states, the Commonwealth formally re-acknowledged that it should be responsible for its election commitments' and that 'the legitimate and additional financial implications for the States and Territories' (COAG Communiqués, 28 March and 3 July 2008) would be part of the final determination by treasurers of the new generation SPPs. Politically, the fragile unity of COAG was disrupted when the Labor Government in Western Australia under Premier Alan Carpenter, following a surprise early election, was replaced in September by Colin Barnett's Liberal-National coalition. And, most ominously, governments were beginning to appreciate the intensity and depth of the storm clouds enveloping both developed and developing economies in what became known in Australia as the global financial crisis (GFC).

When COAG met on 29 November, Rudd and Treasurer Wayne Swan engaged in a frenetic day of final bargaining over additional resourcing before leaders emerged to announce that an historic Intergovernmental Agreement on Federal Financial Relations had been signed, rationalising over 90 SPPs down to just five. The communiqué reaffirmed that these new 'cooperative working arrangements' were aimed at improving services by 'reducing Commonwealth prescriptions on service delivery by the States', providing them 'with increased flexibility in the way they deliver services to the Australian people'. This also enabled 'a clearer specification of roles and responsibilities of each level of government and an improved focus on accountability for better outcomes and better service delivery' (COAG Communiqué, 29 November 2008: 2). Performance reporting and analysis (including data quality issues) would be coordinated by an expanded COAG Reform Council and the Productivity Commission would report to the nation's leaders every two to three years on the 
economic impacts and benefits of this complex reform program. While this new financial arrangement has been recognised as a pro-federalist innovation, the Commonwealth retained a degree of conditionality in certain priority reform areas through the new national partnership payments (Anderson and Parkin 2010: 99, 102-03).

Early childhood undertakings were pared back to fulfilling the core election commitment through one such national partnership payment for ECE - a five-year agreement providing $\$ 955$ million for states and territories to implement the universal access to preschool commitment by 2013 and $\$ 15$ million for data development and evaluation. ${ }^{12}$ There had been 35 (since expanded to 38) child and family centres already agreed to in the Indigenous Early Childhood Development national partnership signed off in October (see Figure 7.1). Quality standards and a rating system for ECEC and the broader ECD strategy were postponed for future COAG agendas. It was, nevertheless, a singular achievement, recognised externally, that the major building block of universal access had been signed off by all political leaders and that the nation's intergovernmental body now had early childhood integrated into its national reform agenda (Kronemann 2008: 3, 32).

Deborah Brennan, a keen observer and analyst of early childhood policies, later hailed the government's early childhood reform agenda, including this national partnership on ECE, as a considerable achievement, while nevertheless drawing attention to the gaps, weaknesses and inconsistencies that remain in Australia's ECEC approach (Brennan 2011). An associated but unheralded reform has been the structural move, following the Commonwealth's lead, of ECE into the education portfolio in those states and territories where this had been administered in other departments. ${ }^{13}$

12 There was also a national partnership developed by the Skills and Workforce Development Subgroup with the assistance of the ECD Subgroup, to deliver the Commonwealth election commitment to fund states for the removal of TAFE fees for diplomas and advanced diplomas of children's services courses.

13 Such machinery of government changes largely took place during 2008, except in New South Wales, where ECEC was finally moved into the education portfolio following the state election in 2011. In Western Australia, child care is still administered in Communities portfolio; in all other jurisdictions, education and care is integrated under education. At the national level, from December 2014 until November 2015, child care was located in the Department of Social Services. It is currently back with the Education and Training Department. 


\section{The MLG elements of COAG'S ECE processes}

With the intergovernmental agreement signed, it was hardly surprising that the working group structure was disbanded early in 2009, although a National Early Childhood Development strategy group continued to meet to take forward the unfinished agenda. PAWG and its subgroups had been 'fit for purpose' for the chaotic period of drafting the new education agreements, but it was not seen as an ongoing governance arrangement. As a bold experiment in reshaping federal relations, however, its core features appear closer to the MLG concept than to classic federalism, particularly in the case of the new policy agenda that was being rolled out in early childhood, which had the advantage of a relatively low political profile. From the EU experience, MLG is likely to be more evident in 'low politics' issues, where the stakes are less significant and the politics are less fraught (Bache and Flinders 2004: 199).

In another mark of difference, after that first COAG meeting in December 2007, traditional hierarchical processes were overtaken by the degree of urgency for the review of SPPs and the public emphasis on collaborative arrangements between the two tiers of government to produce the desired outcomes. The usual vehicle of ministerial councils working under the aegis of COAG was set aside; senior Commonwealth and state line department officials were instead brought onto PAWG and its subgroups, along with central agency representatives. For state officials, especially those from central agencies, working under the direct oversight of the Commonwealth education portfolio minister to formulate recommendations to COAG, was a unique and somewhat disconcerting experience. The non-involvement of state education ministers unsurprisingly created difficulties for some state officials. A senior state official who sat on both the subgroup and PAWG has confirmed those difficulties and suggested, with hindsight, that they might have been smoothed over if a meeting involving these ministers had been held early in the process.

In the ECD subgroup, this mixed membership came from the departments of Prime Minister and Cabinet, Premier and Cabinet, Treasury, Finance, Education and Community Services, with each jurisdiction determining which agencies would represent them. Such a horizontal dimension played out, moreover, inside the two levels of government outside the subgroup meetings, given the constant need for checking in and 
reassessing jurisdictional positions on the shifting agenda - particularly in the middle of the year, when the early childhood agenda was broadened to incorporate a wider spectrum of ECD proposals. Within this horizontally structured, more flexible subgroup, continuous negotiation and constant communication were the hallmarks of its operating style, as decisions taken might be quickly superseded by further advice from the central COAG Secretariat, Treasury or COAG itself.

It was, from an insider's perspective, an exhilarating, exhausting, fastpaced and relentless slog, conducted through robust and, at times, heated and even passionate discussions. Speed in negotiation was possible, due to the priority accorded the agenda and the relationships and degree of trust that had developed. This was tested when the Commonwealth decided to ask the group to broaden its already large agenda to develop a proposal for integrated Child and Family Centres: this was agreed to over the phone by jurisdictions in the space of an afternoon and without formal papers.

The first meeting of the subgroup was facilitated and chaired by an external consultant with senior bureaucratic experience, and this innovation helped to break down the normal Commonwealth/state reserve. ${ }^{14}$ Following this, frequent and extended subgroup meetings facilitated the development of a significant depth of understanding of jurisdictional challenges and key policy considerations; it built, moreover, a degree of camaraderie as the subgroup explored the dimensions of this new national sphere of social policy. The Commonwealth's early offer of $\$ 10$ million for the states to invest immediately in universal access projects to help the most disadvantaged children laid the groundwork for a new relationship of working more cooperatively together and learning about state priorities. The Commonwealth was also more transparent with regard to the available funding and distribution methodology. For their part, state representatives were more prepared within the subgroup environment to provide relatively open assessments of their capabilities and challenges in achieving universal preschool coverage.

14 This was Mary Ann O'Loughlin, then with The Allen Consulting Group but subsequently appointed as head of the COAG Reform Council. She had been a deputy secretary in the Australian public service and had also worked in Prime Minister Keating's office. Coincidentally, the first meeting was held on the day of Prime Minister Rudd's 'Sorry' speech, which committed the Commonwealth to a new target of quality preschool for all Indigenous four-year-olds in remote communities. 
Queensland, for example, was 'coming from behind', having recently added an extra year of formal schooling that was partly achieved by discontinuing their government delivery of sessional preschool. ${ }^{15}$ Victoria and South Australia, with high preschool enrolments but some gaps in coverage and hours offered, were keen to shape the national policy debate. New South Wales, on the other hand, where preschool fees and availability were sensitive issues and where the community services portfolio had functional responsibility for ECE, took a lower profile than they did, for example, on the schooling subgroup. Across jurisdictions, the most significant barriers to achieving universal access to preschool, inevitably, were for Indigenous four-year-olds, notably those living in remote and rural areas.

Compared to the tenor of Commonwealth-state meetings in the education sphere over the previous decade, discussions on the ECD subgroup were conducted in a less adversarial and more informal atmosphere. The COAG expectation of a cooperative working arrangement set the tone for discussions in PAWG and, correspondingly, the ECD subgroup. As an emerging issue, early childhood operated to an extent 'under the radar' and, compared to the schools agenda, was not weighed down by the years of polarised debate on sensitive issues. Working on a policy landscape characterised by such diversity, underinvestment by government and variable quality supplied an incentive to consider more innovative solutions to the complex policy problems inherent in the Commonwealth's commitment to achieve universal access to preschool within a comparatively short five-year window. Greater collaboration, innovation and relative informality frequently are characteristic features of an MLG approach.

Two significant reforms incorporated into the national partnership agreement on ECE underlined the power of these more collaborative and, at times, innovative discussions in the ECD subgroup. The first, which was specifically acknowledged in the agreement, was the adoption of differential funding for the first four years, in order to provide a greater share to Queensland and the Northern Territory, which had further to go to reach the universal access goal, including the specific target for

15 In September 2008, this major gap in preschool access was addressed when Premier Anna Bligh announced a six-year plan for Queensland to reintroduce preschool, utilising the community and private sector for delivery, backed by a $\$ 300$ million infrastructure program for new kindergarten services (Queensland Premier 2008). 
Indigenous children living in remote areas. In the debates in the subgroup, the recognition that some jurisdictions faced a greater challenge and also the internal data analysis and funding options developed by the DEEWR representatives had enabled an informed discussion on the impact of differential funding in the initial period to meet the target of universal access to preschool by 2013 across the country. ${ }^{16}$

The second reform initiative, which was also indicated in the agreement, was to reserve central funding of $\$ 15$ million for data development and evaluation to enable development and implementation of a national performance information strategy - a recognition of the need to work together on data quality issues. This was not replicated in the other education agreements and can be attributed both to the 'low politics' of ECE and the inescapable need to invest in data improvements. Working towards the achievement of nationally consistent data would enable reporting on progress against the performance indicators in the agreement and for the broader public accountability signed off by COAG as a key element of the new federal financial relations.

Given the fast and furious nature of the development of the COAG reform package in 2008, this negotiation was a continuous process conducted largely in-house between the two tiers of government. It was a nontransparent 'top-down' decision-making process with broader stakeholder engagement largely conducted through formalised, 'talking head' consultations at key points across the year (Kronemann 2008: 4). Indeed, a criticism levelled at COAG processes more broadly concerns the limited public information that is available on outcomes and the underpinning rationale for decisions (Blayden 2013: 56). Given the sensitivity of the child care market, a notable exception was the deeper consultative processes conducted around the development of quality standards and a national early years learning framework (EYLF) for ECEC. This limited role for non-government actors reinforced the principally Type I MLG nature of these COAG processes for developing the intergovernmental agreement.

16 This was confirmed by a senior state representative on the subgroup, who described the acceptance of differential funding as 'quite remarkable', and put it down to the fact that everyone in the subgroup understood the data and the 'black hole' in Queensland, and that some states had to get more than others if universal access was to be achieved. 


\section{Lessons learnt}

The emphasis by COAG on collaborative working relations did not prove to be long-lived; Anderson and Parkin have observed that, following the first two years, the Rudd Government was more often seen to be attacking the states as impediments to the national achievement of a more effective, consistent and effective policy reform' (Anderson and Parkin 2010: 97). ${ }^{17}$ Indeed, in June 2011, Terry Moran (one of the architects of this agreement in his role as head of Prime Minister and Cabinet), described the intergovernmental agreement as a 'radical, yet poorly understood reform', whose promise, moreover, 'has so far not been fully realized' (Moran 2011). ${ }^{18}$ The archetypal MLG elements evident in this exercise may, however, be replicable in other policy development processes, albeit with adjustments for the differing circumstances and authorising environments. Potentially transferrable practices that worked for the ECD subgroup can be represented in four areas of learnings: the structural arrangements, supporting processes, skill sets and behaviours of the participants, and negotiating style (see Table 7.1).

Table 7.1: COAG Early Childhood Development Subgroup 2008:

What worked - at a glance

\begin{tabular}{|c|c|}
\hline Issue/action & Why important? \\
\hline \multicolumn{2}{|l|}{ Structures } \\
\hline $\begin{array}{l}\text { Fit for purpose committees - Productivity } \\
\text { Agenda Working Group; ECD subgroup }\end{array}$ & $\begin{array}{l}\text { Clarity - tasks were clear, role of } \\
\text { members was clear }\end{array}$ \\
\hline $\begin{array}{l}\text { Membership of ECD subgroup included } \\
\text { central agencies (e.g. Premier and Cabinet, } \\
\text { Treasuries) as well as line agencies }\end{array}$ & $\begin{array}{l}\text { Increased understanding of issues and } \\
\text { options sped up decision-making within } \\
\text { governments }\end{array}$ \\
\hline $\begin{array}{l}\text { Subgroup reported directly to the deputy } \\
\text { prime minister as chair of PAWG }\end{array}$ & Created a strong authorising environment \\
\hline $\begin{array}{l}\text { Overlapping membership of ECD subgroup } \\
\text { and PAWG }\end{array}$ & $\begin{array}{l}\text { Improved PAWG understanding of issues } \\
\text { sped up decision-making }\end{array}$ \\
\hline
\end{tabular}

17 In 2011, the Business Council of Australia, in its submission to a joint parliamentary committee inquiring into federal-state funding agreements, warned that the Commonwealth was moving back to the 'old system' and that there was a proliferation of new agreements since 2008 that reinstated Commonwealth direction over funding (Australian, 3 June 2011: 8).

18 Moran attributed this to some state line departments who were taking time to adapt to this reform, although they had willingly accepted the funding increase, and also noted that some Commonwealth line departments had been slow to adapt to the spirit of the agreement. 


\begin{tabular}{|c|c|}
\hline Issue/action & Why important? \\
\hline \multicolumn{2}{|l|}{ Processes } \\
\hline $\begin{array}{l}\text { First meeting - use of independent ECE } \\
\text { expert as facilitator }\end{array}$ & $\begin{array}{l}\text { Built collaborative atmosphere from the } \\
\text { beginning }\end{array}$ \\
\hline $\begin{array}{l}\text { Extensive meetings (usually monthly); } \\
\text { intensive meetings (often two days in length) }\end{array}$ & $\begin{array}{l}\text { Allowed sufficient time to develop a } \\
\text { common understanding of issues and } \\
\text { sufficient opportunity to form relationships }\end{array}$ \\
\hline $\begin{array}{l}\text { Relatively informal, free-flowing discussion in } \\
\text { meetings, flexible agenda, round-the-table } \\
\text { summaries }\end{array}$ & $\begin{array}{l}\text { Avoided perception that one jurisdiction } \\
\text { was controlling agenda; ensured all } \\
\text { voices heard - big and small jurisdictional } \\
\text { views captured }\end{array}$ \\
\hline \multicolumn{2}{|l|}{ Skills and behaviours } \\
\hline $\begin{array}{l}\text { Members held a mix of expertise in } \\
\text { ECE and/or government funding and } \\
\text { processes }\end{array}$ & $\begin{array}{l}\text { Key issues and problems across all } \\
\text { aspects of the agenda were identified } \\
\text { quickly and this enabled rapid two-way } \\
\text { education of members }\end{array}$ \\
\hline $\begin{array}{l}\text { Collaborative behaviour, particularly by the } \\
\text { Commonwealth; regular use of 'we' meant } \\
\text { the Commonwealth was seen to be listening } \\
\text { and learning from the states }\end{array}$ & $\begin{array}{l}\text { Promoted greater trust, avoided } \\
\text { perception that Commonwealth was } \\
\text { imposing its agenda }\end{array}$ \\
\hline \multicolumn{2}{|l|}{ Negotiation } \\
\hline $\begin{array}{l}\text { Tactic: work on a big vision of ECD while } \\
\text { developing options for implementing } \\
\text { Commonwealth election commitments }\end{array}$ & $\begin{array}{l}\text { Something for everyone, created a sense } \\
\text { of opportunity and a 'blank slate' }\end{array}$ \\
\hline $\begin{array}{l}\text { Work on developing trust and building } \\
\text { relationships }\end{array}$ & $\begin{array}{l}\text { Created a greater willingness to find } \\
\text { solutions to problems, and avoided } \\
\text { adoption of entrenched positions; more } \\
\text { possible on 'low politics' issues }\end{array}$ \\
\hline $\begin{array}{l}\text { Learn as much as possible about different } \\
\text { situation in each jurisdiction }\end{array}$ & $\begin{array}{l}\text { Developed common understanding } \\
\text { of issues, particularly the different } \\
\text { starting positions on universal access } \\
\text { to preschool }\end{array}$ \\
\hline
\end{tabular}

Firstly, the structural arrangements facilitated policy decision-making in an environment of urgency - which tends to characterise much of public policy development in Australia. Both the overarching PAWG and its offshoot, the ECD subgroup, were structured around a horizontal and senior membership that enabled fast decision-making when required; for the subgroup, a degree of overlapping membership with the PAWG (as the chair and some state representatives attended both), kept a strong linkage with the working group's directions and imperatives - that is, with the authorising environment. The direct lines of reporting from PAWG to COAG bypassed the traditional vertical layer of ministerial councils and accelerated the provision of policy advice to COAG and its 
key senior officials committee. For the ECD subgroup, these structural arrangements were complemented by supporting processes emphasising an energetic, more dynamic operating approach that resulted in relatively informal, free-flowing discussions on the difficult elements of the ECE agenda. The pattern was one of meeting often and for lengthy periods to grapple with the fast-moving agenda and diverse work program. Through such intensive meetings, there was greater capacity to develop a common understanding of the policy challenges at both jurisdictional and national levels and the key elements of a vision for improved ECE services. It is unusual for time-pressured senior bureaucrats to have such an opportunity to interact intensively around a new policy agenda, especially an area such as ECE, which excites strong and passionate views.

Undoubtedly the mix of skill sets and behaviours fostered in the subgroup served to create a more positive environment for negotiation of the most difficult issues. Expertise around the table incorporated subject matter experts; those with broader education and community services sectoral understandings, including Indigenous service delivery; and those more attuned to intergovernmental relations and funding vehicles. The collaborative behaviours auspiced by COAG were manifested in such features as the inclusive language adopted ('we' and 'us') and the specific practice of using 'around the table' views to enable the perspectives of small and large jurisdictions to be captured. Certainly, from a Commonwealth perspective, the political alignment at the ministerial level and deliberate focus on cooperation enabled a more open and frank relationship with state counterparts to be developed after several years of more cautious dealings.

The negotiating style for key decisions adopted in the subgroup, informed by such close engagement with the issues, was based on the need to bring all parties together on central issues - while avoiding the "joint decisionmaking trap' as far as possible. This helped to offset the disadvantage inherent in being provided with the 'one' solution of universal access to preschool, rather than having been able to debate openly the range of potential solutions to Australia's fragmented ECE delivery and policies. The focus on an idealistic 'big picture' for how early childhood services could be enhanced and strengthened tended to offset and make more acceptable the Commonwealth's inevitable preoccupation with delivery of the government's early childhood election commitments. For state officials, a strength of the subgroup was the fact that the Commonwealth was seen to be listening to, and learning from, them. 
Of course, this is not to downplay that there were significant tensions, given the diversity of policy approaches and the time pressures that foreshortened debate on some key issues. Most importantly, with the narrowing of the process to a focus on universal access delivery, there was no agreement on a coherent national policy framework for ECE, and the work of the subgroup became more of a 'slog'. The details of how the states would deliver universal access to preschool within five years and how they would involve the non-government sectors in this delivery were left for resolution in the development of state bilateral plans in the next year. The broader National Early Childhood Development strategy had a bumpy ride and was not agreed and released by COAG (in a very light touch' form), until 2 July 2009. Collecting data on every child in their first year of school for the AEDI was not agreed until the Commonwealth government found more money to cover teacher costs.

In addition, when the GFC hit and the Commonwealth pulled back from the proposed child and family centres and the 260 early childhood centres, there was an uneasy period of reassessing the policy directions, given that an important opportunity to create a new and integrated delivery landscape had been lost. In particular, the states that had not received many or any of the first tranche of 38 centres, and who now missed out, had some disappointment to swallow. Nevertheless, the ECD subgroup showed that it is possible for the two tiers of government to work together closely to achieve mutually agreed objectives in a more collaborative environment, exemplifying a broader trend under COAG to encourage the growth of 'new bureaucratic networks across State borders' (Anderson quoted in Blayden 2013: 59).

The key players inside government during 2008 would not have described or recognised the exercise they were immersed in as an example of MLG; if pressed, they might have pragmatically labelled it as an instance of Australian federalism adapting to the exigencies of the contemporary environment, with its emphasis on increasing productivity and investing in human capital. At the same time, they were aware that they were engaged in something new and different - a 'fascinating process' as one state official described it, which was 'bold and unusual' but 'offered something good and worthwhile'. It was characterised by a new and less traditionally hierarchical way of working together, a novel design in structural arrangements, a new focus on objectives and outcomes over inputs, and a new emphasis on accountability and monitoring as the trade-off for the removal of restrictive conditions in the Commonwealth's 
grants. The novelty of these year-long, less than perfect discussions was captured by Russell Ayres, branch manager in OECECC, who was closely involved in the ECD subgroup:

What we had created in the National Partnership for Early Childhood Education was all new. It was new (and major) funding; it was a new form of intergovernmental agreement; and it was a new way for government to work with the early childhood education and care sector (at least at the national level).

This episode of working through a new policy agenda confirmed that an MLG approach can deliver results, notwithstanding that ECE reform remained a work in progress at the end of 2008. But this approach was reliant on a fragile balance of power in Commonwealth-state relations that was dependent on the Commonwealth's willingness to cede power. This supportive environment appears to have dissipated in subsequent years, as the Commonwealth shifted its focus towards greater centralisation, amid tension in what was once again a politically divided federation.

\section{References}

Anderson, G. \& Parkin, A. (2010). Federalism: A fork in the road? In: Aulich, C. \& Evans, M. (eds) The Rudd Government: Australian Commonwealth Administration 2007-2010. ANU E Press, Canberra.

Bache, I. (2004). Multi-level Governance and European Union Regional Policy. In: Bache, I. \& Flinders, M. (eds) Multi-level Governance. Oxford University Press. doi.org/10.1093/0199259259.003.0010

Bache, I. \& Flinders, M. (eds) (2004). Multi-level Governance. Oxford University Press. doi.org/10.1093/0199259259.003.0012

Banks, G. (2009). Evidence-Based Policy Making: What is it? How do we get it? Australia and New Zealand School of Government. ANU Public Lecture Series, Canberra, 4 February 2009.

Blayden, L. (2013). COAG Briefing Paper No 6/2013. NSW Parliamentary Research Service, Sydney, July 2013. 
Brennan, D. (2011). 'Investing in Childhood: The Progress and the Pitfalls'. Inside Story: Current Affairs and Culture from Australia and Beyond. Swinburne Institute for Social Research, 25 August 2011, insidestory.org.au/investing-in-childhood-the-progress-and-thepitfalls/ [Accessed: 10/05/2017].

COAG Communiqués (2006-09). webarchive.nla.gov.au/gov/20070829 161008/http://coag.gov.au/meetings/archive.htm; www.coag.gov.au/ coagmeetingoutcomes/index.cfm [Accessed: 13/12/2014].

Dowling, A. \& O'Malley, K. (2009). Preschool Education in Australia. Australian Council for Educational Research, Melbourne.

Elliott, A. (2006). Early Childhood Education Pathways to Quality and Equity for All Children. Australia Education Review. Australian Council for Educational Research, Melbourne.

Fenna, A. (2004). Australian Public Policy. 2nd edn. Pearson Longman, Frenchs Forest, NSW.

—. (2009). Federalism. In: Rhodes, R.A.W. (ed.) The Australian Study of Politic. Palgrave Macmillan, Chippenham and Eastbourne. doi.org/ 10.1057/9780230296848_11

Gillard, The Honourable J. (2008). Ministerial Statement 13 May 2008. Commonwealth Budget Education Revolution 2008-09. Commonwealth Government, Canberra.

Kronemann, M. (2008). Aboriginal and Torres Strait Islander Children and the National Early Childhood Agenda. An Initial Discussion Paper. Dusseldorp Skills Forum, Melbourne.

Marks, G. (1993). Structural Policy and Multilevel Governance in the EC. In: Cafruny, A. \& Rosenthal, G. (eds) The State of the European Community Vol. 2: The Maastricht Debates and Beyond. Longman, Harlow, pp. 391-410.

McKew, M. (2013). Tales from the Political Trenches. Melbourne University Press, Carlton, Victoria.

Mercer, T. (2016). 'Universal Preschool: The rocky path to policy change'. ANZSOG case study, www.anzsog.edu.au/resource-library/case-library/ universal-preschool-the-rocky-path-to-policy-change-2016-176-1 [Accessed 11/10/17]. 
Miragliotta, N., Errington, W. \& Barry, N. (2010). The Australian Political System in Action. Oxford University Press, South Melbourne.

Moran, T. (2011). Speech to Eidos Institute, An Australian public policy think tank. Brisbane. 8 June.

OECD (2008). Education at a Glance 2008. Organisation for Economic Co-operation and Development, Paris.

Painter, M. (1996). The Council of Australian Governments and Intergovernmental Relations: A case of cooperative federalism. Publius: The journal of federalism 26(2) (Spring).

Queensland Premier (2008). Message from Queensland Premier, TowardQ2, September, cabinet.qld.gov.au/documents/2009/jun/ toward\%20q2\%20qld\%20next\%20steps/Attachments/Q2\%20 Summary.pdf [Accessed: 15/12/14].

Rudd, K. \& Macklin, J. (2007). New Directions for Early Childhood Education. Universal access to early learning for 4 year olds. Australian Labor Party, January 2007.

Steering Committee for the Review of Government Services Provision (2009). Report on Government Services 2009. Vol. 1. Melbourne.

Stein, M. \& Turkewitsch, L. (2008). The Concept of Multi-level Governance in Studies of Federalism. Paper Presented at the 2008 International Political Science Association International Conference, Concordia University, Montreal, Quebec, Canada.

Vromen, A., Gelber, A. \& Gauja, A. (2009). Powerscape Contemporary Australian Politics. Allen and Unwin, Crows Nest, NSW. 
This text is taken from Multi-level Governance: Conceptual challenges and case studies from Australia, edited by Katherine A. Daniell and Adrian Kay, published 2017 by ANU Press, The Australian National University, Canberra, Australia.

dx.doi.org/10.22459/MG.11.2017.07 